\title{
Malate synthase from Corynebacterium glutamicum : sequence analysis of the gene and biochemical characterization of the enzyme
}

\author{
Dieter J. Reinscheid, Bernhard J. Eikmanns and Hermann Sahm
}

Author for correspondence: Bernhard J. Eikmanns. Tel : +492461 61 3967. Fax: +492461612710.

Institut für Biotechnologie des Forschungszentrums Jülich, D-52425 Jülich, Germany
Malate synthase is one of the key enzymes of the glyoxylate cycle and is essential for growth on acetate as sole carbon source. The aceB gene from Corynebacterium glutamicum, encoding malate synthase, was isolated, subcloned and expressed in Escherichia coli and C. glutamicum. Sequencing of a 3024 bp DNA fragment containing the aceB gene revealed that it is located close to the isocitrate lyase gene aceA. The two genes are separated by 597 bp and are transcribed in divergent directions. The predicted ace $B$ gene product consists of 739 amino acids with an $M_{r}$ of 82362 . Interestingly, this polypeptide shows only weak identity with malate synthase polypeptides from other organisms and possesses an extra $\mathbf{N}$-terminal sequence of about 170 amino acid residues. Inactivation of the chromosomal ace $B$ gene led to the absence of malate synthase activity and to the inability to grow on acetate, suggesting that only one malate synthase is present in C. glutamicum. The malate synthase was purified from an aceB-overexpressing $C$. glutamicum strain and biochemically characterized. The native enzyme was shown to be a monomer migrating at an $\boldsymbol{M}_{\mathrm{r}}$ of about $\mathbf{8 0 0 0 0}$. By sequencing the $\mathbf{N}$-terminus of malate synthase the predicted translational start site of the enzyme was confirmed. The enzyme displayed $K_{\mathrm{m}}$ values of $30 \mu \mathrm{M}$ and $12 \mu \mathrm{M}$ for the substrates glyoxylate and acetyl COA, respectively. Oxalate, glycolate and ATP were found to be inhibitors of malate synthase activity. The present study provides evidence that the malate synthase from $C$. glutamicum is functionally similar to other malate synthase enzymes but is different both in size and primary structure.

Keywords: Corynebacterium glutamicum, acetate metabolism, glyoxylate cycle, malate synthase, isocitrate lyase

\section{INTRODUCTION}

Utilization of acetate or fatty acids as sole carbon sources requires the operation of the glyoxylate cycle as an anaplerotic pathway for replenishing $\mathrm{C} 4$ molecules of the tricarboxylic acid (TCA) cycle (Kornberg, 1966). Key enzymes of the glyoxylate cycle are isocitrate lyase (EC 4.1.3.1) and malate synthase (EC 4.1.3.2), which bypass the decarboxylation steps of the TCA cycle. Isocitrate lyase cleaves isocitrate to give succinate and glyoxylate and malate synthase catalyses the irreversible

Abbreviation: $W T$, wild-type.

The GenBank/DDBJ accession number for the sequence reported in this paper is $X 78491$. aldol condensation of glyoxylate and acetyl CoA to form malate and $\mathrm{CoA}$.

Malate synthase has been biochemically characterized from a variety of organisms (reviewed by Cioni et al., 1981), including some bacteria such as Eschericbia coli, Bacillus stearothermophilus and Psendomonas ovalis (Chell \& Sundaram, 1975, 1978; Falmagne \& Wiame, 1973; Dixon et al., 1960). The properties of the purified malate synthases are similar with respect to $K_{\mathrm{m}}$ values, specific activity, inhibitors and requirement of $\mathrm{Mg}^{2+}$ for activity. The prokaryotic enzymes are monomers $\left(M_{\mathrm{r}} \approx 60000\right)$ whereas the eukaryotic malate synthases are homomultimers with subunit sizes corresponding to the prokaryotic enzymes. Besides biochemical characterization of the enzyme, genes coding for malate synthase have been 
cloned and sequenced from E. coli (Maloy \& Nunn, 1982; Byrne et al., 1988) and from several eukaryotes, e.g. Saccharomyces cerevisiae, Neurospora crassa, Aspergillus nidulans, Brassica napus, Candida tropicalis and cucumber (Hartig et al., 1992; Fernandez et al., 1993; Thomas et al., 1988; Sandemann et al., 1991; Comai et al., 1989; Hikida et al., 1991; Graham et al., 1989). The genes encoding malate synthase are generally only expressed during growth on acetate, glyoxylate or compounds which are metabolized to acetate, acetyl $\mathrm{CoA}$ or glyoxylate, e.g. fatty acids, ethanol or allantoin (Kornberg, 1966; Armitt et al., 1976; Sandemann \& Hynes, 1989; Hikida et al., 1991; Hartig et al., 1992; Fernandez et al., 1993). In E. coli, the malate synthase gene $a c e B$ was found to be organized in an operon together with the ace $A$ gene encoding isocitrate lyase and the ace $K$ gene coding for isocitrate dehydrogenase-kinase/phosphatase, which is involved in the regulation of isocitrate dehydrogenase (Brice \&: Kornberg, 1968; Maloy \& Nunn, 1982; Chung et al., 1988; LaPorte et al., 1985).

Corynebacterium glutamicum is a Gram-positive organism widely used in the industrial production of primary metabolites, e.g. amino acids (Liebl, 1991). The organism is able to grow on acetate and, accordingly, both isocitrate lyase and malate synthase activities are present in it (Kinoshita, 1985). It has been shown that acetate also serves as substrate for the production of amino acids such as glutamate, lysine and threonine (reviewed in Kinoshita \& Tanaka, 1972). In some production strains, the formation of threonine was even higher in the presence of acetate than on glucose minimal medium (Akashi et al., 1979), suggesting that the glyoxylate cycle may be an important target in the genetic construction of defined amino-acid-producing strains. Therefore, we initiated genetic and biochemical studies on both the isocitrate lyase and the malate synthase of $C$. glutamicum. The isocitrate lyase has recently been biochemically characterized and the respective ace $A$ gene has been cloned and sequenced (Reinscheid et al., 1994). As in E. coli, expression of the ace $A$ gene was found to be tightly regulated; however, several lines of evidence suggested that in $C$. glutamicum the ace $A$ gene is not transcriptionally linked to the ace $B$ gene and, thus, the two genes have an organization different from that in E. coli. In the present study we describe the cloning of the $C$. glutamicum malate synthase gene $a c e B$, its nucleotide sequence and the deduced amino acid sequence. We show data about the homologous and heterologous expression of ace $B$ and its chromosomal inactivation in C. glutamicum and, finally, we present the purification and biochemical analysis of the malate synthase enzyme.

\section{METHODS}

Bacteria, plasmids and culture conditions. The bacterial strains and plasmids used in this study are listed in Table 1. M9 medium (Sambrook et al., 1989) was used as minimal medium for E. coli; the minimal medium used for $C$. glutamicum has been described previously (Eikmanns et al., 1991b) and contained $4 \%(\mathrm{w} / \mathrm{v})$ glucose, $2 \%(\mathrm{w} / \mathrm{v})$ acetate, or $1 \%(\mathrm{w} / \mathrm{v})$ glucose plus $1 \%$ $(\mathrm{w} / \mathrm{v})$ acetate. LB medium (Sambrook et al., 1989) was used as the complex medium for both organisms. For the growth of $E$. coli DV21 A05 on glucose minimal medium, succinate was added at $15 \mathrm{mM}$. When appropriate, ampicillin $\left(100 \mu \mathrm{g} \mathrm{ml}^{-1}\right)$ or kanamycin $\left(50 \mu \mathrm{g} \mathrm{ml}^{-1}\right)$ was added to the medium. Both organisms were grown under aerobic conditions, $E$. coli at $37^{\circ} \mathrm{C}, \mathrm{C}$. glutamicum at $30^{\circ} \mathrm{C}$.

DNA preparation and transformation. Plasmids from E. coli were isolated by the method of Birnboim (1983). Chromosomal DNA from C. glutamicum was obtained as described previously (Eikmanns, 1992). Transformation of C. glutamicum was performed by electroporation (Liebl et al., 1989) and E. coli was transformed by the $\mathrm{CaCl}_{2}$ method (Sambrook et al., 1989).

DNA manipulations. All restriction enzymes, T4 DNA ligase, Klenow polymerase and calf intestine phosphatase were obtained from Boehringer Mannheim and used as instructed by the manufacturer. Restriction-generated fragments were separated on $0 \cdot 8 \%$ agarose gels and isolated and purified by using the Geneclean kit (Dianova; Bio 101).

DNA hybridization experiments were performed as described previously (Reinscheid et al., 1994). The $0.84 \mathrm{~kb} S m a \mathrm{I}-K p n \mathrm{I}$ fragment isolated from plasmid $\mathrm{pEKB} 1$ and the $0.92 \mathrm{~kb}$ Asp700-BfrI fragment isolated from plasmid pEKA2 were labelled with digoxigenin-dUTP and used as probes.

For sequencing, the $1.61 \mathrm{~kb} B f r \mathrm{I}-K p n \mathrm{I}$ fragment and the $1.79 \mathrm{~kb}$ HindIII-PvuI fragment from plasmid pAB-17 were blunt-ended and ligated into plasmid pUC18. From the resulting plasmids progressive unidirectional deletions of the inserted DNA were created using the Erase-a-base kit from Promega. Sequencing was performed by the dideoxy chain-termination method (Sanger et al., 1977) using the AutoRead sequencing kit from Pharmacia with subsequent electrophoretic analysis with an A.L.F. DNA sequencer from Pharmacia. Sequence data were compiled and analysed by the HUSAR program package from EMBL.

Gene disruption. Gene disruption was performed as described previously by Schwarzer \& Pühler (1991). An aceB internal $0.42 \mathrm{~kb} S p b \mathrm{I}-K p n \mathrm{I}$ fragment was blunt-ended and ligated into the $S_{c a l}$ site of the mobilizable E. coli vector pSUP301, which is nonreplicative in $C$. glutamicum. The resulting plasmid was introduced into $C$. glutamicum via conjugation from $E$. coli S17-1. The conjugation was performed as described by Schäfer et al. (1990); the transconjugants were selected on LB agar plates containing kanamycin $\left(15 \mu \mathrm{g} \mathrm{ml}^{-1}\right)$ and nalidixic acid $\left(50 \mu \mathrm{g} \mathrm{ml}^{-1}\right)$.

Malate synthase assay. To determine malate synthase activity, cells were grown in $60 \mathrm{ml}$ medium in $500 \mathrm{ml}$ baffled Erlenmeyer flasks to the exponential growth phase, washed twice in $20 \mathrm{ml}$ $50 \mathrm{mM}$ Tris/ $\mathrm{HCl}$ buffer, $\mathrm{pH} 7 \cdot 6$, and resuspended in $1 \mathrm{ml}$ of the same buffer. Cells were disrupted by sonication with a microtipequipped sonifier (Branson) at maximum settings for $10 \mathrm{~min}(C$. glutamicum) or for $2 \mathrm{~min}\left(\right.$ E. coli) at $0^{\circ} \mathrm{C}$. After centrifugation for $30 \mathrm{~min}$ at $13000 \mathrm{~g}$ the supernatant was used as crude extract. The protein concentration was determined by the Biuret method (Gornall et al., 1949) using bovine serum albumin as standard. Malate synthase was assayed photometrically at $232 \mathrm{~nm}$ and $30^{\circ} \mathrm{C}$ according to a modified method described by Dixon \& Kornberg (1959). In a final volume of $1 \mathrm{ml}$, each assay contained $50 \mathrm{mM}$ Tris/ $\mathrm{HCl}, \mathrm{pH} \mathrm{7.6,40 \textrm {mM } \mathrm { MgCl }}, 0.24 \mathrm{mM}$ acetyl CoA, $2 \mathrm{mM}$ sodium glyoxylate and malate synthase or crude extract. One unit (U) of activity corresponds to $1 \mu \mathrm{mol}$ malate formed per min. Michaelis constants were obtained by using a Lineweaver-Burk double-reciprocal plot and inhibition constants were determined from linear replots of LineweaverBurk slopes versus inhibitor concentrations (Segel, 1975).

Purification of malate synthase. Crude extracts for purification 
Table 1. Bacterial strains and plasmids

\begin{tabular}{|c|c|c|}
\hline Strain/plasmid & Relevant characteristics* & Source/reference \\
\hline \multicolumn{3}{|l|}{ Strains } \\
\hline E. coli DV21A05t & $\begin{array}{l}\text { lacZ43, relA1, }(s p e C-g l c) 63, \text { spoT1, ppc-2, thi-1, } \\
\text { aceB6, } \mathrm{Hfr}\end{array}$ & $\begin{array}{l}\text { Vanderwinkel \& De } \\
\text { Vlieghere (1968) }\end{array}$ \\
\hline E. coli $\mathrm{S} 17-1$ & Mobilizing donor strain & Simon et al. (1983) \\
\hline C. glutamicum WT & WT strain ATCC 13032 & $\begin{array}{l}\text { American Type } \\
\text { Culture Collection }\end{array}$ \\
\hline \multicolumn{3}{|l|}{ Cosmids/plasmids } \\
\hline $\mathrm{pHC} 79$ & $\mathrm{Ap}^{\mathrm{R}} \mathrm{Tet}^{\mathrm{R}}$ & Hohn \& Collins $(1980)$ \\
\hline $\begin{array}{l}\text { pHC79-based } \\
\text { gene library }\end{array}$ & $\begin{array}{l}\text { C. glutamicum chromosomal DNA cloned in } \\
\text { cosmid pHC79 }\end{array}$ & Börmann et al. (1992) \\
\hline $\mathrm{pACB} 1$ & $\begin{array}{l}\text { Recombinant cosmid able to complement E. coli } \\
\text { DV21A05 }\end{array}$ & This work \\
\hline pACYC184 & $\mathrm{Cm}^{\mathrm{R}} \mathrm{Tet}^{\mathrm{R}}$ ori $\mathrm{P} 15 \mathrm{~A}$ & Chang \& Cohen (1978) \\
\hline pAB-17 & $\begin{array}{l}\text { pACYC184 containing a } 5.5 \mathrm{~kb} \text { insert from } \\
\text { cosmid pACB1 }\end{array}$ & This work \\
\hline $\mathrm{pEKO}$ & E. coli-C. glutamicum shuttle vector, $\mathrm{Ap}^{\mathrm{R}} \mathrm{Km}^{\mathrm{R}}$ & Eikmanns et al. (1991a) \\
\hline pEKB1 & $\begin{array}{l}\text { pEK0 containing a } 3 \mathrm{~kb} B f r \mathrm{I}-P \nu u \mathrm{I} \text { fragment from } \\
\text { pAB-17 }\end{array}$ & This work \\
\hline pEKA2 & $\begin{array}{l}\text { pEK0 containing a } 2.4 \mathrm{~kb} H p a \mathrm{I}-N c i \text { fragment } \\
\text { carrying the } C \text {. glutamicum ace } A \text { gene }\end{array}$ & Reinscheid et al. (1994) \\
\hline pUC18 & $\mathrm{Ap}^{\mathrm{R}}$ & $\begin{array}{l}\text { Vieira \& Messing } \\
(1982)\end{array}$ \\
\hline pSUP301 & Mobilizable vector, ori $T, \mathrm{Km}^{\mathrm{R}}$ & Simon et al. (1983) \\
\hline
\end{tabular}

${ }^{*} \mathrm{Cm}^{\mathrm{R}}$, chloramphenicol resistance; $\mathrm{Tet}^{\mathrm{R}}$, tetracycline resistance; $\mathrm{Km}^{\mathrm{R}}$, kanamycin resistance; $\mathrm{Ap}^{\mathrm{R}}$, ampicillin resistance.

† This strain was kindly provided by Barbara Bachmann, E. coli Genetic Stock Center, New Haven, USA.

of malate synthase were prepared as described above except that the cells were washed in $50 \mathrm{mM}$ 2-morpholinoethanesulphonic acid (MES) buffer, $\mathrm{pH} 6.0$, and resuspended in $10 \mathrm{ml}$ of the same buffer containing $5 \mathrm{U}$ DNase, $15 \mu \mathrm{g}$ RNase and $100 \mu \mathrm{M}$ phenylmethanesulphonyl fluoride (PMSF). All purification steps were carried out at $4{ }^{\circ} \mathrm{C}$. After ultracentrifugation of the crude extract at $183000 \mathrm{~g}$, the supernatant was subjected to FPLC anion-exchange chromatography using a MonoQ HR5/5 column with a $0 \cdot 1-0 \cdot 4 \mathrm{M} \mathrm{NaCl}$ gradient (flow rate: $1 \mathrm{ml} \mathrm{min}^{-1}$ ). For the second chromatography the buffer of the partially purified enzyme was changed to $50 \mathrm{mM}$ Tris $/ \mathrm{HCl}, \mathrm{pH} 8$, by ultrafiltration with an Ultrafree filter cup (Millipore). During the second MonoQ HR5/5 chromatography $50 \mathrm{mM}$ Tris $/ \mathrm{HCl}$, $\mathrm{pH} 8$, was used with a $0.2-0.5 \mathrm{M} \mathrm{NaCl}$ gradient and a flow rate of $1 \mathrm{ml} \mathrm{min}{ }^{-1}$.

SDSPAGE, gel filtration and determination of the $\mathrm{N}$-terminus of malate synthase. SDS-PAGE was performed using a Hoefer Studier vertical slab gel instrument (Serva) in $12.5 \%(\mathrm{w} / \mathrm{v}$ ) polyacrylamide gels overnight at $8 \mathrm{~mA}$ according to the method of Laemmli (1970). Gel filtration was performed by FPLC using a Superdex 200 column (Pharmacia). The buffer consisted of $100 \mathrm{mM}$ Tris/ $\mathrm{HCl}, \mathrm{pH} 7 \cdot 6,100 \mathrm{mM} \mathrm{NaCl}$ and $5 \mathrm{mM} \mathrm{MgCl}$. Protein standards were catalase $\left(M_{\mathrm{r}} 232000\right)$, aldolase $\left(M_{\mathrm{r}}\right.$ $158000)$, BSA $\left(M_{\mathrm{r}} 67000\right)$ and ovalbumin $\left(M_{\mathrm{r}} 43000\right)$. For determination of the malate synthase $\mathrm{N}$-terminus, the purified enzyme was subjected to SDS-PAGE, transferred to a polyvinylidene difluoride membrane filter and sequenced using an Applied Biosystems 477A sequenator equipped with a Blot cartridge and an on-line HPLC apparatus 120.

\section{RESULTS}

\section{Isolation of the C. glutamicum malate synthase gene aceB}

In order to isolate the ace $B$ gene from $C$. glutamicum a pHC79-based cosmid gene library from this organism was transformed into the E. coli mutant DV21 A05. Due to its malate synthase deficiency strain DV21A05 is not able to grow on acetate minimal medium (Vanderwinkel \& De Vlieghere, 1968). By testing approximately 1000 transformants for growth on acetate minimal medium three clones were obtained which grew on acetate as carbon source. After isolation of the cosmids $\mathrm{pACB} 1, \mathrm{pACB} 2$ and $\mathrm{pACB} 3$ and retransformation into E. coli DV21A05, the transformants again grew on acetate minimal medium, suggesting that the cosmids carried the $C$. glutamicum ace $B$ gene.

In order to subclone the ace $B$ gene, cosmid pACB1 was partially digested with Sau3A and fragments between 3 and $6 \mathrm{~kb}$ were ligated into the BamHI site of the E. coli vector $\mathrm{pACYC184}$. The ligation mixture was transformed into E. coli DV21A05 and chloramphenicol-resistant transformants were again screened for growth on acetate minimal medium. By this procedure nine clones carrying plasmids able to complement the malate synthase deficiency of E. coli DV21A05 were obtained. The 
(a)

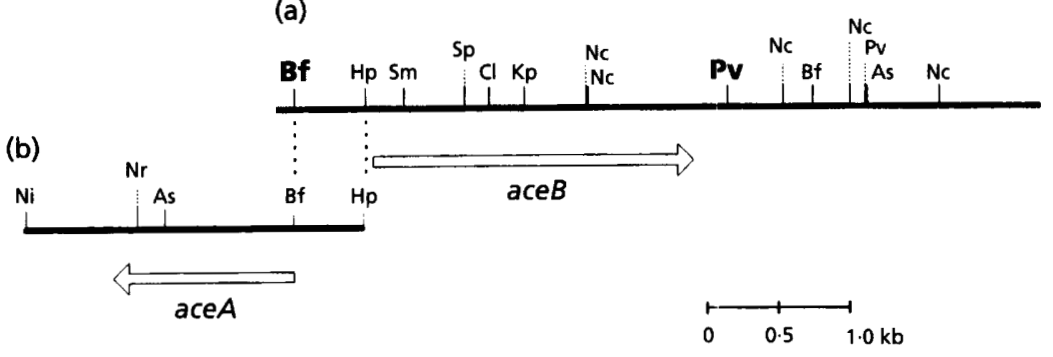

Fig. 1. Restriction maps of the chromosomal C. glutamicum fragments carrying (a) the malate synthase gene $a c e B$ and (b) the isocitrate lyase gene ace $A$. The fragment sequenced in the present study is marked by bold letters. The respective open reading frames are indicated by arrows. As, Asp700: $\mathrm{Bf}, \mathrm{Bfrl} ; \mathrm{Cl}, \mathrm{Clal} ; \mathrm{Hp}, \mathrm{Hpal} ; \mathrm{Kp}, \mathrm{Kpnl} ; \mathrm{Nc}$, Ncol; Ni, Ncil; Nr, Nrul; Pv, Pvul; Sm, Smal; Sp, Sphl.

\section{Table 2. Specific activities of malate synthase in crude extracts of $E$. coli and C. glutamicum strains}

The cells were grown in minimal medium (MM) containing glucose or acetate as carbon source. The values are means \pm standard deviation obtained from at least three independent cultivations by two determinations per experiment. NG, No growth.

\begin{tabular}{|c|c|c|}
\hline \multirow[t]{2}{*}{ Strain } & \multicolumn{2}{|c|}{$\begin{array}{l}\text { Malate synthase activity } \\
{\left[\mathrm{U}(\mathrm{mg} \text { protein })^{-1}\right]}\end{array}$} \\
\hline & $\mathbf{M M}+$ glucose & MM + acetate \\
\hline E. coli DV21A05 & $<0.01$ & NG \\
\hline E. coli DV21A05 pHC79 & $<0.01$ & NG \\
\hline E. coli DV21A05(pAC1) & $0 \cdot 35 \pm 0 \cdot 06$ & $0 \cdot 30 \pm 0 \cdot 03$ \\
\hline E. coli DV21A05(pAB-17) & $0 \cdot 29 \pm 0 \cdot 04$ & $0 \cdot 24 \pm 0 \cdot 04$ \\
\hline E. coli DV21 A05(pEKB1) & $0 \cdot 24 \pm 0 \cdot 02$ & $0 \cdot 29 \pm 0 \cdot 04$ \\
\hline C. glutamicum WT & $0.04 \pm 0.01$ & $2 \cdot 11 \pm 0 \cdot 22$ \\
\hline C. glutamicum $(\mathrm{pEK} 0)$ & $0.04 \pm 0.01$ & $2 \cdot 23 \pm 0 \cdot 13$ \\
\hline C. glutamicum (pEKB1) & $0 \cdot 35 \pm 0 \cdot 04$ & $6 \cdot 22 \pm 0 \cdot 40$ \\
\hline C. glutamicum ALB1 & $<0.01 *$ & NG \\
\hline
\end{tabular}

* When $C$. glutamicum ALB1 was grown in minimal medium containing glucose plus acetate, malate synthase activity could also not be detected.

restriction map of the $5.5 \mathrm{~kb}$ insert from one of the plasmids, pAB-17, is shown in Fig. 1(a).

To localize the $a c e B$ gene more precisely, defined fragments were isolated out of plasmid pAB-17 and ligated into the E. coli-C. glutamicum shuttle vector, $\mathrm{pEK} 0$. The resulting plasmids were transformed into $E$. coli DV21 A05 and tested for complementation ability. By this procedure, plasmid pEKB1 was obtained carrying a $3 \mathrm{~kb}$ $B f r I-P v u I$ fragment which was able to complement the $E$. coli mutant.

Southern hybridization was performed to confirm that the cloned $3 \mathrm{~kb} B f r \mathrm{I}-P v u \mathrm{I}$ fragment originated from $C$. glutamicum. Chromosomal DNA from C. glutamicum wildtype (WT) was digested with $B f r \mathrm{I}$ and $P v u \mathrm{I}$, sizefractionated and transferred onto a nulon membrane. A $0.84 \mathrm{~kb} S m a \mathrm{I}-K p n I$ fragment was isolated from pEKB1, labelled and used as a probe. This fragment hybridized specifically to a chromosomal fragment of $3 \mathrm{~kb}$ (not shown) confirming that the isolated aceB-complementing fragment originates from $C$. glutamicum and that it corresponds to a fragment within the genome with no detectable structural alteration.

\section{Malate synthase activity in E. coli and C. glutamicum}

The specific malate synthase activities in crude extracts of E. coli DV21 A05 clones carrying cosmid pAC1, plasmid pAB-17 or pEKB1 were determined after growth on minimal medium containing glucose or acetate. As shown in Table 2 the three strains displayed considerable malate synthase activities [between 0.24 and $0.35 \mathrm{U}$ (mg protein $)^{-1}$ ] both after growth on glucose and acetate minimal medium. No malate synthase activity was detected in the host E. coli DV21A05 and in E. coli DV21A05 carrying cosmid pHC79 without insert (Table 2). These results confirm that the isolated fragments contained the malate synthase gene from C. glutamicum and show that it is expressed in E. coli.

For homologous expression of the isolated ace $B$ gene, plasmid pEKB1 was introduced into C. glutamicum WT and the specific malate synthase activities of the host and of the transformant, C. glutamicum(pEKB1), were determined (Table 2). After growth on glucose minimal medium the recombinant strain displayed about ninefold higher specific malate synthase activity relative to $C$. glutamicum WT or its derivative carrying the cloning vector pEK0. When acetate minimal medium was used for growth, the specific malate synthase activities of C. glutamicum WT and $C$. glutamicum $(\mathrm{pEK} 0)$ were approximately 50 -fold higher than after growth on glucose minimal medium, and that of $C$. glutamicum (pEKB1) was still threefold higher compared to the host (Table 2). These results show that the malate synthase of $C$. glutamicum is tightly regulated by the carbon source and indicate that the isolated $B f r \mathrm{I}-P v u \mathrm{I}$ fragment carries the ace $B$ gene including the structures necessary for expression and regulation in $C$. glutamicum.

\section{Nucleotide sequence of the ace $B$ gene}

The DNA sequence of the 3024 bp BfrI-PvuI fragment was determined from both strands by the dideoxy chaintermination method. The complete nucleotide sequence of the $C$. glutamicum ace $B$ gene including $5^{\prime}$ and $3^{\prime}$ regions and the deduced amino acid sequence of the malate synthase is shown in Fig. 2. Computer analysis revealed 


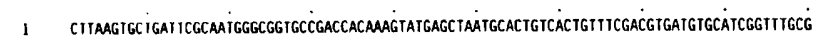

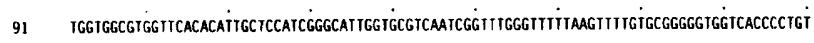

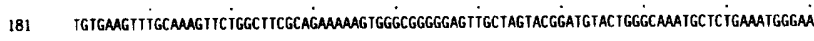

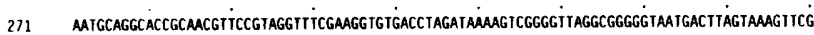

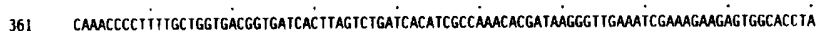

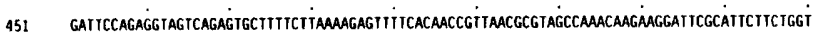

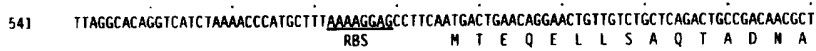
631 GGAAC TGACAGCACCGAACGCGTIGACGCGGGCGGATGCAGGI IGCAAAAGTICTCTACGACTITGTAACCGAAGCGGTACTCCC TCG G T D S T E R D A G G Q V A K V L Y D F GTGGGTGTGGATGCGGAAAGTTCIGGTCCGGATTCGCCGCCATCGCCCGGGACCICACCCCACGCAACCGGAGCTGCTIGCTCGCCGC

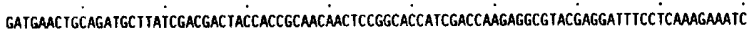
D E I Q H L I D D Y H R N N S G I I D Q E A Y E D F L K E I

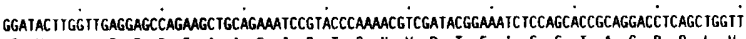
G Y L VEE E P E A A E I R T Q N V D T E I S S I A G P Q L V

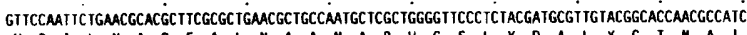
Y P I L A E A L A A M A R G S L Y D A L Y G T M A I

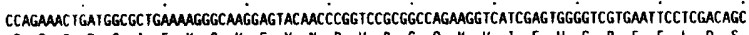
PE I D G A E K GKE Y N P VRG QK VIE HEREFL DS

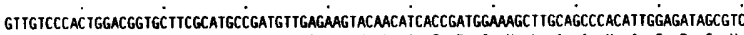
$V V P L D G A S S H A D V E K Y$ N I T D G K L A A H I G D S V taCCGACI GianaCCGTGAATCCTACCGIGGCTICACCGGCAACTTCCTtGATCCAGAaGCAATCCTGCTGGAAACCAACGGCCTGCAC Y R L K N R E S Y R G F T G N F L D P E A I L L E T N G L H

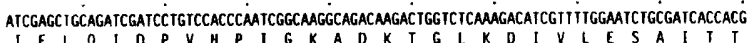

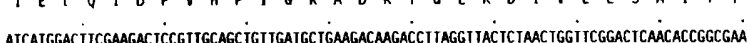
I M D F E D S V A A V D A E D K T L G Y S N WFG L N T G E

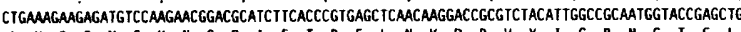
$L K E E M S K M G R I F T R E L$ N K D R V Y I G R N G I E L GITCTGCACGG TCGTICCCTGCTGTTCGTCCGCAAGGTIGGTCACCTCATGCAAACCCATCCATCTTGATTGATGGGGGGAGATCTIC V L H G R S L L F VR N VG H L M Q N P S I L I D GE E I F

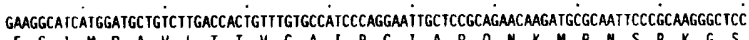

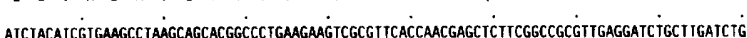
I Y I V K P K Q H G P E E VAF T N E L F G R VE D L L D L

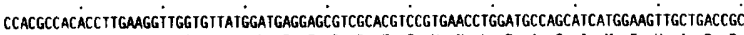
PRHTLK V G V A DEERRTS V N L D A S I HE VA D R IIGGCAIICATCAACACTGGCTICCTGGACCGCACCGGGGATGAATCCACACCTCCAIGGAGGCAGGCGCCATGGIGCGCAGGGTGAT $L A F I M I G F$ I $R$ I G D I H I S M E G A M V R K A D

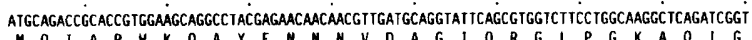
H Q I A P

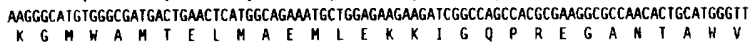

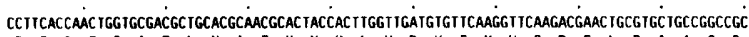
P S P T G A T L HA T H Y HL VDVFKVQDELRA A G R

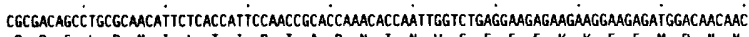
R D S L R N I L T I P I A IGCCAGTCCATCCTCGGATACGTIGTGCGCTGGGTTGAGCACGGGTTGGTIGCTCCAGGITCCAGACATCCATGACATCGACCTCATG

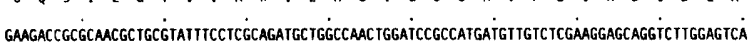

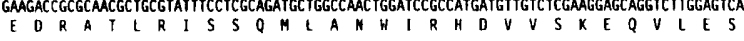

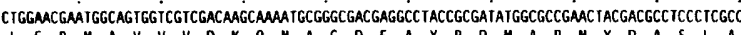
if F O A A K O L I F E G I K S P S G YT E P I L H A R R R E F

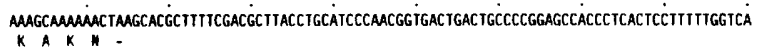

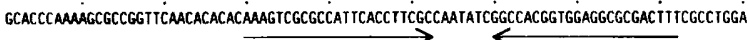
itccacaccacagtggaicatgaccaitciccctcaatggitgatgatgcigatcg

Fig. 2. Nucleotide sequence of the 3024 bp Bfr-Pvul fragment carrying the ace $B$ gene from $C$ glutamicum. The predicted amino acid sequence of the malate synthase is shown below the nucleotide sequence. A putative ribosome-binding site is indicated as RBS and a potential terminator structure is marked by arrows.

one large open reading frame (ORF) extending from nucleotide 586 to 2802 and exhibiting a codon usage corresponding to highly expressed corynebacterial genes (Eikmanns, 1992). The predicted translational initiation codon at nucleotide 586 is preceded by a typical ribosomal binding site. Downstream of the ORF, at positions 2910-2962 in Fig. 2, a potential rho-independent termination structure was found. According to the rules of Tinoco et al. (1973) this palindromic structure should be capable of forming a stem-loop with a $\Delta G\left(25^{\circ} \mathrm{C}\right)$ of $-41 \mathrm{kcal} \mathrm{mol}^{-1}\left(-172 \cdot 2 \mathrm{~kJ} \mathrm{~mol}^{-1}\right)$. The ORF encodes a polypeptide of 739 amino acids with an $M_{\mathrm{r}}$ of 82362 . Since no other ORF of significant size was found in either orientation on the BfrI-PvuI fragment, it was evident that the predicted polypeptide represents the malate synthase from $C$. glutamicum and the ORF was therefore named aceB.

\section{Comparison of the deduced malate synthase amino acid sequence from C. glutamicum with those of other organisms}

Comparison of the deduced amino acid sequence of the $C$. glutamicum malate synthase with sequences of enzymes from other organisms revealed only weak similarity. Whereas the predicted $C$. glutamicum ace $B$ gene product consists of 739 amino acids, malate synthases of other organisms consist of between 533 and 568 amino acids (for overviews, see Hikida et al., 1991 and Fernandez et al., 1993), suggesting that the C. glutamicum enzyme is larger by at least 170 amino acids. Within the N-terminal 200 amino acids of the $C$. glutamicum malate synthase no similarity at all to other malate synthases could be detected. However, since residues important for the catalytic mechanism may be found among conserved amino acids, the deduced amino acid sequence of the $C$. glutamicum malate synthase starting at amino acid 160 was aligned with the malate synthase sequences of $E$. coli (Byrne et al., 1988), S. cerevisiae (Hartig et al., 1992; Fernandez et al., 1993), the ascomycete $N$. crassa (Sandemann et al., 1991) and of the plant Brassica napus (Comai et al., 1989) (Fig. 3). The aligned region of the $C$. glutamicum enzyme shows less than $15 \%$ identity to any of the other malate synthases, whereas these show overall identities of between 42 and $49 \%$ among each other and possess several highly conserved regions (underlined in Fig. 3). It is striking that the few amino acids identical in all five aligned sequences are primarily located within these highly conserved regions.

\section{The ace $B$ gene is located in close proximity to the ace $A$ gene}

Recently, we isolated and sequenced a $2.43 \mathrm{~kb} H p a \mathrm{I}-\mathrm{N} c \mathrm{I}$ fragment (Fig. 1b) carrying the $C$. glutamicum ace $A$ gene encoding isocitrate lyase (Reinscheid et al., 1994). Comparison of the nucleotide sequence of this $H p a I-N c i \mathrm{I}$ fragment with that of the aceB-carrying $B f r I-P v u I$ fragment revealed that both fragments share a common region, i.e. the first 504 nucleotides of the $B f r \mathrm{I}-P v u \mathrm{I}$ fragment in Fig. 2 corresponded to the inverted nucleotide sequence in front of the ace $A$ gene. From these data it could be predicted that in $C$. glutamicum the ace $B$ gene is clustered together with ace $A$, that both genes are separated by 597 bp and that they are oriented in opposite directions. 
CGMS

ECMS

SCMS

NCMS

BNMS

CGMS

ECMS

SCMS

NCMS

BNMS

CGMS

ECMS

SCMS

NCMS

BNMS

CGMS

ECMS

SCMS

NCMS

BNMS

CGMS

ECMS

SCMS

NCMS

BNMS

CGMS

ECMS

SCMS

NCMS

BNMS

CGMS

ECMS

SCMS

NCMS

BNMS
...GTNAIPETDGAEKGKEYNPVRGQKVIEWGREFLDSVVPLDGASHADVEKYNITDGKLAAHIGDSVYRLKNRESYRGFTGNFLDPEAILLE MTEQAT-_-_-_-_TDELAFTRPYGEQEKQILTAEAVEFLTELVTHFTPQR--NKLLAARIQQQQD IDNGTLP-DF ISETASIRD $M---V K V S L--O N V K L L V D V D K E P F F K P S S T T V G D I L T K D A L E F I V L L H R T F N N K R--K Q L L E N R Q V V Q K K L D S G S Y H L D F L P E T A N I R N$ M---ASVE--..---TLLQGVTISG---PIEEHQRKILTPQALSFVALLHRSFNQTR--KNLLERRHVRQAE IDRGVLP-DFLPETKHIRE MELETSVY--RPNVAVYDSPDGVEVRGRYDQVFAKILTRDALGFVAELQREFRGHV--RYAMECRREVKRRYNSGAVP-GFDPSTKFIRD SS SS

S

$\star \quad S S$

TNGLHIELQIOPVHPIGKADKTGLKDIVLESAITTIMDFEDSVAAVDAEDKTLGYSNWFGLNTGELKEEMSKMGRIFTRELNKDRVYIGR A-DWK-IRG IPADLEDRRVE I TGPVERKM--.---VINALNANVKVFMADFEDSLAPDWNKVIDGQINLRDAVNGT ISYTNEA-GKIYQLK DPTWQ-GPILAPGLINRSTE I TGPPLRNM-----LINALNAPVNTYMTDFEDSASPTWNNMVYGQVNLYDDAIRNQIDFDTPR--KSYKLN NPTWKGAAPAAPPLVDRRVEMTGP TDRKM-----VVNALNSDVYTYMADFEDSSAPTWANMVNGQVNLYDAIRRQIDFKQGP --KEYKLG-EWV-CASVPPAVADRRVEITGPVERKM-----IINALNSGAKVFMADFEDALSPSWENLMRGOVNLKDAVDGSITFNDKARNKVYKLN $S * \star S \quad S \quad s \quad s * s \quad s$ *

NGTELVLHGRSLLFVRNVGHLMQNPSILIDGEE IFEGIMDAVLITVCAIPG IAPQNKMRNSRKGSIYIVKPKQHGPEEVAFTNELFGRVE PN---P----AVLICRVRGLHLPEKHVTWRGEAIPGSLFDFALYFFHWYQAL---.-.--LAKGSGPYFYLPKTQSWQEAAWWSEVFSYAE GN---V-ANLPTI IVRPRGWHMVEKHL YVDDEP ISASI FDFGLYFYHNAKEL------I IKLGKGPYFYLPKMEHHLEAKLWNDVFCVAQ RTDRTL----PTLIVRPRGWHLEEKHVTIDGEPVSGSLFDFGLYFFHNAKEL-------VQRGFGPYFYPPPKMESHLEARLWNDAFNLAQ DQ---V----AKLFVRPRGWHLPEAHILIDGEPATGCLVDFGLYYFFHMYAKF----RQTQGSGFGPFFYLPKMEHSREAKIWMSVFERAE $S \star s \quad S * 5 * \star$

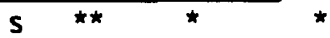
*

DLLDLPRHTLKVGVMDEERRTSVNLDASIMEVADRLAFINTG---FLDRTGDEIHTSMEAGAMVRKADMQTAPWKQAYENNNVDAGIQRG DRFNLPRGTIKATLLIETLPAVFQMDEILHALRDHIVGLNCGRWDYIFSYIKTLKNYPDRVLPDRQAVTMDKPFLNAYSRLLIKTCHKRG DYIGIPRGRIRATVLIETLPAAFQMEE I IYQLRQHSSGLNCGRWDY IFST I KRLRNDPNHILPNRNQVTMTSPFMDAYVKRLINTCHRRG DYVGIPLSTIRGTVLIET I TAAFEMDE I IFELRNHTSGLNRGGWDYIFPFI IEEVRRFPNFVLPDRSDVVTMTVPFMEAYVKLL IKTLHRLV KMAGIERGSIRATVLIETLPAVFOMNEILYELLRDHSVGLNCGRHDYIFSYVKTFQAHPDRLLPDRVLVGMGQHFMRSYSDLLIRTCHKRG

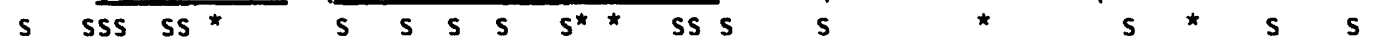

LPGKAQIGKGMWAMTELMAEMLEKKIGQPREGANTAWVPSPTGATLHATHYHL-VDVFKVQDELRAAGRRDSLRNILTIPTAPNTNWSEE AFAMGGMAAF IPSKDEEHNNQV-LN-KVKADKSLEANNGHDGTWIAHPGLADTAMAVFNDILGSRKNQLEVMREQDAPITADQLLAPCDG VHAMGGMAAQIP IKDOPAANEKAMTKVRN-DKIREL TNGHDGSWVAHPALAP ICNEVFINMG-TPNQIYFIPENVVTAAN-LLETKIPNG VHAMG-MAAQIP I KDDKAANDKAMEGVVRADKLREARAGHDGTWVAHPALASIALEVFNKHMPTPNQLFNRREDVKIGQQDLLNMNVP-G VHAMGGMAAOIP IRDDPKANEMALD-LVKKDKLREVRAGHDGTWAAHPGLIPICMDAFSHMGNNPNQIKSMKRDDASAITEEDLLQIPRG

$$
\text { S S }
$$

EKKEE-MDNNCQSILGYVVRWVEHGVGCSKVPDIHDIOLMEDRATLRISSQMLANWIRHDVVSKEQVLESLERMAVVVD-.-.-.---KQ ERTEEGMRANIRVAVQYIEAWI-SGNGCVP-----IYGLMEDAATAE ISRTSIWQWIHHQKTLSN---GKPVTKALFRQMLGEEMKVIAS EITTEGIVQNLDIGLQYMEAWL-RGSGCVP--..-- INNLMEDAATAEVSRCQL YQWVKHGVTLLKDTG--EKVTPELTEKILKEQVERLSK SSTEDG IRKNLNTGL GYTEPWI-RGVGCVP-----I KHPQEDAATAEVSRSQLWQWVKHRVTTAAEGK--HVDKRYPLKLLKEADRQRLAK VRTLEGLRLNTRVGIQYLAAWL-TGSGSVP....-- LYNLMEDAATAEISRVQNWQWIRYGVELDGDGLGVRVSKELFGRVVEEEMERIEK
- NAGDEAYRDMAPNYDASLAFQAAKDLIFEGTKSPSGY TEPILHARRREFKAKN
-ELGEERFSQGRFDDAARLMEQITTSOELIDFLTLPGYRLLA-.....-..-.-

Fig. 3. Alignment of the predicted malate synthase sequences from C. glutamicum (CGMS), E. coli (ECMS) (Byrne et al., 1988), S. cerevisiae (SCMS) (Hartig et al., 1992; Fernandez et al., 1993), N. crassa (NCMS) (Sandemann et al., 1991), and B. napus (BNMS) (Comai et al., 1989). Identical and similar amino acids are marked by * and s, respectively. Regions of high identity between the enzymes from $E$. coli, S. cerevisiae, N. crassa and B. napus are underlined.

To ensure that both genes are clustered on the $C$. glutamicum chromosome, Southern hybridization was performed. An aceB-specific $0.84 \mathrm{~kb} S m a \mathrm{I}-K p n \mathrm{I}$ fragment and an ace $A$-specific $0.92 \mathrm{~kb} A s p 700-B f r \mathrm{I}$ fragment (see Fig. $1 \mathrm{a}$ and $\mathrm{b}$ ) were used as probes. Hybridization of Asp700-digested chromosomal C. glutamicum WT DNA to the ace $A$-specific and the ace $B$-specific probes resulted in both cases in a signal at $4.9 \mathrm{~kb}$ (not shown). This result was expected from the combined restriction maps of the ace $A$ - and ace $B$-carrying fragments (see Fig. 1). Thus, the ace $A$ and ace $B$ genes of $C$. glutamicum are in fact clustered and oriented in antiparallel direction as shown in Fig. 1. 
Table 3. Purification of malate synthase from crude extracts of $C$. glutamicum(pEKB1) after growth in acetate minimal medium

\begin{tabular}{|c|c|c|c|c|c|c|}
\hline Fraction & $\begin{array}{l}\text { Vol. } \\
\text { (ml) }\end{array}$ & $\begin{array}{l}\text { Total } \\
\text { protein } \\
\text { (mg) }\end{array}$ & $\begin{array}{c}\text { Total } \\
\text { activity } \\
\text { (U) }\end{array}$ & $\begin{array}{c}\text { Specific } \\
\text { activity } \\
\text { [U (mg } \\
\left.\text { protein })^{-1}\right]\end{array}$ & $\begin{array}{c}\text { Recovery } \\
\text { of activity } \\
(\%)\end{array}$ & $\begin{array}{c}\text { Purification } \\
\text { factor } \\
\text { (-fold) }\end{array}$ \\
\hline Crude extract* & $2 \cdot 3$ & $66 \cdot 7$ & $415 \cdot 4$ & $6 \cdot 2$ & 100 & $1 \cdot 0$ \\
\hline Ultracentrifugation & $18 \cdot 0$ & $30 \cdot 8$ & $408 \cdot 2$ & $13 \cdot 3$ & 98 & $2 \cdot 1$ \\
\hline MonoQ, $\mathrm{pH} 6.0$ & $3 \cdot 0$ & $3 \cdot 9$ & $109 \cdot 2$ & $27 \cdot 8$ & 26 & $4 \cdot 5$ \\
\hline MonoQ, pH 8.0 & $2 \cdot 0$ & $3 \cdot 5$ & $101 \cdot 4$ & $28 \cdot 6$ & 24 & $4 \cdot 6$ \\
\hline
\end{tabular}

* Prepared from $1 \mathrm{~g}$ cells (wet weight).

\section{Inactivation of the chromosomal aceB gene in $C$. glutamicum}

To investigate whether C. glutamicum requires a functional $a c e B$ gene for growth, the chromosomal ace $B$ gene of $C$. glutamicum WT was inactivated by gene disruption. The resulting strain, C. glutamicum ALB1, was then tested for malate synthase activity and for growth on different media. The specific malate synthase activity was determined in crude extracts of $C$. glutamicum ALB1 after growth in minimal medium containing glucose or glucose plus acetate as carbon sources. As shown in Table 2 strain ALB1 was devoid of detectable malate synthase activity. Growth of $C$. glutamicum ALB1 on minimal medium containing glucose as carbon source was identical to that of the parental C. glutamicum WT. However, in contrast to the WT strain, C. glutamicum ALB1 was not able to grow on acetate as sole carbon source. When a mixture of acetate and glucose was given as carbon source, growth of C. glutamicum ALB1 was significantly impaired in comparison to the parental strain (doubling times of $180 \mathrm{~min}$ and $100 \mathrm{~min}$, respectively). It can be speculated that due to malate synthase deficiency the mutant accumulates glyoxylate internally and this might be detrimental for the cells. These results show that the ace B gene in $C$.glutamicum ALB1 is inactivated and that $C$. glutamicum requires a functional $a c e B$ gene for growth on acetate. It can therefore be suggested that in $C$. glutamicum only one malate synthase exists.

\section{Purification and characterization of malate synthase}

The analysis of the ace $B$ gene from $C$. glutamicum and the alignment studies suggested that malate synthase from this organism differs significantly from hitherto known malate synthases both in size and primary structure. In order to obtain information about the biochemical characteristics of the $C$. glutamicum enzyme, the malate synthase was purified and biochemically analysed. The aceB-overexpressing strain C. glutamicum(pEKB1) was grown on acetate minimal medium and used for purification of the malate synthase. Table 3 summarizes the purification procedure and gives representative data of the preparation. The enzyme was purified $4 \cdot 6$-fold to apparent homogeneity (Fig. 4), indicating that malate synthase represents about $20 \%$ of the cytoplasmic protein

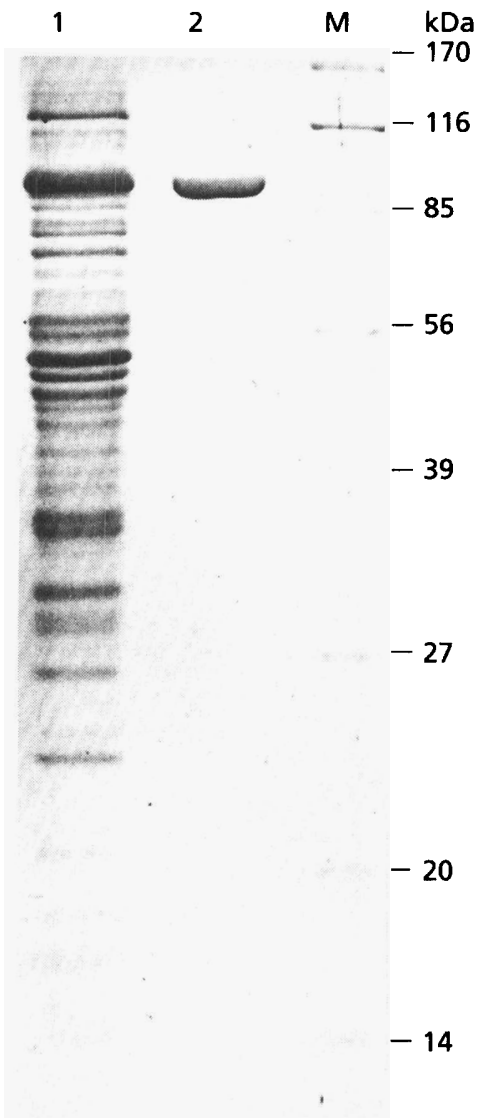

Fig. 4. SDS-PAGE of crude extract from C. glutamicum(PEKB1) after growth in acetate minimal medium (lane 1) and SDS-PAGE of purified malate synthase (lane 2). $M_{\mathrm{r}}$ standards (lane $\mathrm{M}$ ): $\alpha_{2^{-}}$ macroglobulin (170 kDa), $\beta$-galactosidase (116 kDa), fructose- 6 phosphate kinase $(85 \mathrm{kDa})$, glutamate dehydrogenase $(56 \mathrm{kDa})$, aldolase $(39 \mathrm{kDa})$, triosephosphate isomerase $(27 \mathrm{kDa})$, trypsin inhibitor $(20 \mathrm{kDa})$, and lysozyme (14 kDa).

fraction within $C$. glutamicum (pEKB1). This value is in good agreement with the relative amount of malate synthase that can be seen after SDS-PAGE of crude extracts from acetate-grown C. glutamicum (pEKB1) (Fig. 4). The SDS-PAGE analysis of the purified enzyme revealed a single protein band with an $M_{\mathrm{r}}$ of about 90000 
(Fig. 4), which corresponds reasonably well to the $M_{1}$ predicted from the $a c e B$ sequence (82362, see above). By gel filtration the native $M_{\mathrm{r}}$ of malate synthase was determined to be about 80000 . These results suggest that the malate synthase from C. glutamicum is a monomer in its native form and confirm that the $C$. glutamicum enzyme is in fact significantly larger than the hitherto known malate synthase monomers from other organisms (for overviews, see Cioni et al., 1981; Hikida et al., 1991; Fernandez et al., 1993).

In order to confirm the predicted translational initiation site, the $\mathrm{N}$-terminus of purified malate synthase was sequenced. The amino acid sequence obtained was T-EQ-E-L-L-S-A-Q-T and thus corresponds to the sequence deduced from the nucleotide sequence of the ace $B$ gene. The missing methionine in the purified malate synthase suggests that it is removed by processing.

The purified $C$. glutamicum malate synthase remained stable at $4{ }^{\circ} \mathrm{C}$ for more than 3 weeks without loss of activity. The enzyme showed a $\mathrm{pH}$ optimum of 7.6 in $50 \mathrm{mM}$ Tris/ $\mathrm{HCl}$ buffer, a temperature optimum of $43^{\circ} \mathrm{C}$ and exhibited an absolute requirement for divalent cations. Maximum activity was observed in the presence of $40 \mathrm{mM} \mathrm{Mg}^{2+} \cdot \mathrm{Co}^{2+}$ or $\mathrm{Mn}^{2+}$ could partially replace $\mathrm{Mg}^{2+}$ resulting in $25 \%$ and $15 \%$, respectively, of the maximal activity. The $K_{\mathrm{m}}$ values determined for acetyl $\mathrm{CoA}$ and glyoxylate were $12 \mu \mathrm{M}$ and $30 \mu \mathrm{M}$, respectively, which is in the same range as previously reported for malate synthases from other organisms (Cioni et al., 1981).

To analyse whether malate synthase is regulated on the enzymic level, its inhibition by several effectors was studied. Oxalate and glycolate, both structural analogues of glyoxylate, were found to be competitive inhibitors with regard to glyoxylate. The inhibition constants of oxalate and glycolate were $0.27 \mathrm{mM}$ and $0.44 \mathrm{mM}$, respectively. ATP turned out to be a competitive inhibitor versus acetyl CoA showing an inhibition constant $\left(K_{\mathbf{i}}\right)$ of $4.3 \mathrm{mM}$. No effect on enzyme activity was observed with fructose-1,6-bisphosphate, pyruvate, phosphoenolpyruvate, acetyl phosphate or with any intermediate of the citric acid cycle. From these results we assume that in $C$. glutamicum the inhibition or activation of the malate synthase plays only a minor role in controlling the carbon flux in the glyoxylate cycle.

\section{DISCUSSION}

The data reported above describe the isolation and characterization of the C. glutamicum malate synthase gene $a c e B$. To our knowledge, this is the first $a c e B$ gene isolated from a Gram-positive organism, and besides that of E. coli it represents the only malate synthase gene sequenced from a prokaryote. By sequence analysis and hybridization studies, evidence was provided that the ace $B$ gene in $C$. glutamicum is clustered together with the isocitrate lyase gene ace $A$, which has been isolated and sequenced previously (Reinscheid et al., 1994). Both genes are transcribed divergently and thus the genomic organization of ace $B$ and ace $A$ is different from that in $E$. coli. In this organism, and probably also in Salmonella typhimurium, the two genes constitute an operon together with the isocitrate dehydrogenase-kinase/phosphatase gene ace $K$ in the order ace $B$-ace $A$-aceK (Brice \& Kornberg, 1968; Maloy \& Nunn, 1982; Wilson \& Maloy, 1987; Chung et al., 1988; Cortay et al., 1989). The expression of this ace-operon is negatively controlled by the $i c l R$ and $f a d R$ gene products in a trans-dominant manner (Maloy \& Nunn, 1982), and due to this regulation both malate synthase $A$ and isocitrate lyase are only formed when acetate or long-chain fatty acids are the sole carbon sources. In C. glutamicum, the formation of both enzymes is also drastically increased during growth on medium containing acetate (Reinscheid et al., 1994; this work). However, the antiparallel genomic organization of the ace $B$ and ace $A$ genes in $C$. glutamicum predict that in contrast to $E$. coli both genes are expressed independently by their own promoters. This poses the interesting question about the co-ordinated regulation of the $C$. glutamicum ace $B$ and ace $A$ gene expression. It is likely that the two genes are controlled by the same regulatory mechanism, perhaps even at the same site on the DNA. Both genes may also be regulated differentially in their expression allowing adaptation to growth under conditions in which only one of the two enzymes is necessary, e.g. growth on glycolate, glyoxylate or allantoin (Vanderwinkel \& De Vlieghere, 1968; Hartig et al., 1992). However, C. glutamicum is not able to grow on these compounds (unpublished results) and at present our data do not allow any conclusion about the regulation of ace $B$ and ace $A$ expression in C. glutamicum.

Biochemical analysis of the C. glutamicum malate synthase indicates that the native enzyme is a monomer, that it requires divalent cations, that it shows high affinity to its substrates and that it is effectively inhibited by oxalate, glycolate and ATP. With respect to these features the $C$. glutamicum enzyme is very similar to malate synthases purified from other bacteria (Dixon et al., 1960; Chell \& Sundaram, 1975, 1978) and, with the exception of its monomeric nature, also to those from eukaryotes (Cioni $e t$ al., 1981; Okada et al., 1986; Fukawa et al., 1987). Despite these functional similarities, the $C$. glutamicum malate synthase is remarkably different in its size and primary structure. Compared to all other known malate synthases the enzyme from $C$. glutamicum has an extra $\mathrm{N}$-terminal stretch consisting of about 170 amino acids, long enough to form a distinct domain. However, a database search with this $\mathrm{N}$-terminal sequence revealed no similarity to any known sequence in the SwISSPROT database. Since the malate synthases from other organisms lack this $\mathrm{N}$ terminal stretch, it is unlikely that it is essential for catalytic activity or known regulatory features. Thus, the extra $\mathrm{N}$-terminus may have some role in structural stability or in the specificity of an as yet unidentified effector of the enzyme.

In addition to the $\mathrm{N}$-terminal extension of malate synthase from C. glutamicum its primary structure showed only weak similarity to that of other known malate synthases. One possible explanation is that the $C$. glutamicum enzyme shares a common ancestor with the malate synthases from the other organisms but, due to the $\mathrm{N}$-terminal extension 
of the C. glutamicum enzyme, its C-terminal part had to undergo significant changes in primary structure to remain functional. It might also be that the C. glutamicum enzyme is not homologous to the malate synthases from the other organisms. However, we favour the former hypothesis since our alignment shows that several of the identical amino acids within the aligned sequences are located in the highly conserved regions of the malate synthases from other organisms. It is enticing to speculate that these residues are most important for the catalytic and/or regulatory properties of malate synthases. To our knowledge, no specific amino acids involved in the catalytic or regulatory mechanism have yet been identified experimentally and, due to the high identity of all hitherto known malate synthases, it was up to now impossible to propose active site residues by alignment studies. In this context it is worth mentioning that malate synthase and citrate synthase catalyse similar reactions, i.e. a condensation of acetyl CoA and a 2-oxoacid. Citrate synthase from pig-heart has been crystallized and the threedimensional structure elucidated (reviewed by Wiegand \& Remington, 1986). By X-ray analysis, as well as by sitedirected mutagenesis, histidine ${ }_{274}$ and aspartate ${ }_{375}$ were identified as involved in the reaction mechanism (Alter $e t$ al., 1990; Wiegand \& Remington, 1986). It is striking that in the C-terminal region of all malate synthases, including that of the $C$. glutamicum enzyme, a highly conserved histidine and a highly conserved aspartate residue separated by about 80 amino acids could be identified $\left(\mathrm{H}_{564}\right.$ and $\mathrm{D}_{647}$ in the C. glutamicum enzyme). However, further experiments are needed to conclusively identify the amino acids important for the catalytic and the regulatory mechanisms of malate synthase enzymes.

\section{ACKNOWLEDGEMENTS}

We thank M. Romes for preparing the photographs and J. Carter-Sigglow for critical reading of the manuscript. This work was supported by grant BIOT-CT91-0264 (RZJE) from the EC-BRIDGE programme.

\section{REFERENCES}

Akashi, K., Shibai, H. \& Hirose, Y. (1979). Comparison between acetic acid and glucose as a substrate in threonine fermentation. Agric Biol Chem 43, 1563-1566.

Alter, G. M., Casazza, J. P., Zhi, W., Nemeth, P., Srere, P. A. \& Evans, C. T. (1990). Mutation of essential catalytic residues in pig citrate synthase. Biochemistry 29, 7557-7563.

Armitt, S., McCullough, W. \& Roberts, W. (1976). Analysis of acetate non-utilizing $(a c u)$ mutants in Aspergillus nidulans. $J$ Gen Microbiol 92, 263-282.

Birnboim, H. C. (1983). A rapid alkaline extraction method for the isolation of plasmid DNA. Methods Enzymol 100, 243-255.

Börmann, E. R., Eikmanns, B. J. \& Sahm, H. (1992). Molecular analysis of the Corynebacterium glutamicum gdb gene encoding glutamate dehydrogenase. Mol Microbiol 6, 317-326.

Brice, C. B. \& Kornberg, H. L. (1968). Genetic control of isocitrate lyase activity in Escherichia coli. J Bacteriol 96, 2185-2186.

Byrne, C., Stokes, H. W. \& Ward, K. A. (1988). Nucleotide sequence of the ace $B$ gene encoding malate synthase $\mathrm{A}$ in Escherichia coli. Nucleic Acids Res 16, 9342.
Chang, A. C. Y. \& Cohen, S. N. (1978). Construction and characterization of amplifiable multicopy DNA cloning vehicles derived from the P15A cryptic plasmid. J Bacteriol 134, 1141-1156.

Chell, R. M. \& Sundaram, T. K. (1975). Isolation and characterization of isocitrate lyase and malate synthase from Bacillus stearothermopbilus. Biochem Soc Trans 3, 303-306.

Chell, R. M. \& Sundaram, T. K. (1978). Structural basis of the thermostability of monomeric malate synthase from a thermophilic Bacillus. J Bacteriol 135, 334-341.

Chung, T., Klumpp, D. J. \& LaPorte, D. C. (1988). Glyoxylate bypass operon of Escherichia coli: clon' $\sim \sigma$ and determination of the functional map. $J$ Bacteriol 170, 386-39'.

Cioni, M., Pinzauti, G. \& Vanni, P. (1981). Comparative biochemistry of the glyoxylate cycle. Comp Biochem Physiol 70B, 1-26.

Comai, L., Baden, C. S. \& Harada, J. J. (1989). Deduced sequence of a malate synthase polypeptide encoded by a subclass of the gene family. J Biol Chem 264, 2778-2782.

Cortay, J. C., Bleicher, F., Duclos, B., Cenatiempo, Y., Gautier, C., Prato, J. L. \& Cozzone, A. J. (1989). Utilization of acetate in Eschericbia coli: structural organization and differential expression of the ace operon. Biocbimie 71, 1043-1049.

Dixon, G. H. \& Kornberg, H. L. (1959). Assay methods for key enzymes of the glyoxylate cycle. Biochem $J$ 72, 3P.

Dixon, G. H., Kornberg, H. L. \& Lund, P. (1960). Purification and properties of malate synthetase. Biochim Biophys Acta 41, 217-233.

Eikmanns, B. J. (1992). Identification, sequence analysis, and expression of a Corynebacterium glutamicum gene cluster encoding the three glycolytic enzymes glyceraldehyde-3-phosphate dehydrogenase, 3-phosphoglycerate kinase, and triosephosphate isomerase. $J$ Bacteriol 174, 6076-6086.

Eikmanns, B. J., Kleinertz, E., Liebl, W. \& Sahm, H. (1991a). A family of Corynebacterium glutamicum/Escherichia coli shuttle vectors for cloning, controlled gene expression, and promoter probing. Gene 102, 93-98.

Eikmanns, B. J., Metzger, M., Reinscheid, D. J. \& Sahm, H. (1991b). Amplification of three threonine biosynthesis genes in Corynebacterium glutamicum and its influence on carbon flux in different strains. Appl Microbiol Biotechnol 34, 617-622.

Falmagne, P. \& Wiame, J.-M. (1973). Purification et caracterisation partielle des deux malate synthases d'Escherichia coli. Eur J Biochem 37, 415-424.

Fernandez, E., Fernandez, M. \& Rodicio, R. (1993). Two structural genes are encoding malate synthase isoenzymes in Saccharomyces cerevisiae. FEBS Lett 320, 271-275.

Fukawa, H., Ejiri, S. \& Katsumata, T. (1987). Purification and some properties of malate synthase from the pollen of Pinus densiflora Sieb. et Zucc. Agric Biol Chem 51, 1553-1560.

Gornall, A. G., Bardawill, C. J. \& David, M. M. (1949). Determination of serum proteins by means of the Biuret reaction. $J$ Biol Chem 177, 751-766.

Graham, I. A., Smith, L. M., Brown, J. W. S., Leaver, C. J. \& Smith, S. M. (1989). The malate synthase gene of cucumber. Plant Mol Biol 13, 673-684.

Hartig, M., Simon, M. M., Schuster, T., Daugherty, J. R., Yoo, H. S. \& Cooper, T. G. (1992). Differentially regulated malate synthase genes participate in carbon and nitrogen metabolism of Saccharomyces cerevisiae. Nucleic Acids Res 20, 5677-5686.

Hikida, M., Atomi, H., Fukuda, Y., Aoki, A., Hishida, T., Teranishi, Y., Ueda, M. \& Tanaka, A. (1991). Presence of two transcribed malate synthase genes in an $n$-alkane-utilizing yeast, Candida tropicalis. J Biochem 110, 909-914. 
Hohn, B. \& Collins, J. (1980). A small cosmid for efficient cloning of large DNA fragments. Gene 11, 291-298.

Kinoshita, S. (1985). Amino acids. In Biology of Industrial Organisms, pp. 115-142. Edited by A. L. Demain \& N. A. Solomon. London: Benjamin/Cummings Publishing.

Kinoshita, S. \& Tanaka, K. (1972). Glutamic acid. In The Microbial Production of Amino Acids, pp. 263-324. Edited by K. Yamada. New York: John Wiley \& Sons.

Kornberg, H. L. (1966). The role and control of the glyoxylate cycle in Escherichia coli. Biochem J 99, 1-11.

Laemmli, U. K. (1970). Cleavage of structural proteins during the assembly of the head of bacteriophage T4. Nature 227, 680-685.

LaPorte, D. C., Thorsness, P. E. \& Koshland, D. E., Jr (1985). Compensatory phosphorylation of isocitrate dehydrogenase, a mechanism for adaptation to the intracellular environment. $J$ Biol Chem 260, 10563-10568.

Liebl, W. (1991). The genus Corynebacterium - nonmedical. In The Prokaryotes, vol. II, pp. 1157-1171. Edited by A. Balows, H. G. Trüper, M. Dworkin, W. Harder \& K.-H. Schleifer. New York: Springer Verlag.

Liebl, W., Bayerl, A., Schein, B., Stillner, U. \& Schleifer, K. H. (1989). High efficiency electroporation of intact Corynebacterium glutamicum cells. FEMS Microbiol Lett 65, 299--304.

Maloy, S. R. \& Nunn, W. D. (1982). Genetic regulation of the glyoxylate shunt in Escherichia coli K12. J Bacteriol 149, 173-180.

Okada, H., Ueda, M. \& Tanaka, A. (1986). Purification of peroxisomal malate synthase from alkane-grown Candida tropicalis and some properties of the purified enzyme. Arch Microbiol 144, 137-144.

Reinscheid, D., Eikmanns, B. J. \& Sahm, H. (1994). Characterization of the isocitrate lyase gene from Corynebacterium glutamicum and biochemical analysis of the enzyme. J Bacteriol 176, 3474-3483.

Sambrook, J., Fritsch, E. F. \& Maniatis, J. (1989). Molecular Cloning: A Laboratory Manual. Cold Spring Harbor: Cold Spring Harbor Laboratory Press.

Sandemann, R. A. \& Hynes, M. J. (1989). Isolation of the facA (acetyl-coenzyme A synthetase) and acuE (malate synthase) genes of Aspergillus nidulans. Mol \& Gen Genet 218, 87-92.
Sandemann, R. A., Hynes, M. J., Fincham, J. R. S. \& Connerton, I. F. (1991). Molecular organisation of the malate synthase genes of Aspergillus nidulans and Neurospora crassa. Mol \& Gen Genet 228, 445-452.

Sanger, F., Nicklen, S. \& Coulson, A. R. (1977). DNA sequencing with chain-terminating inhibitors. Proc Natl Acad Sci USA 74, 5463-5467.

Schäfer, A., Kalinowski, J., Simon, R., Seep-feldhaus, A. H. \& Pühler, A. (1990). High frequency conjugal plasmid transfer from gram-negative Escherichia coli to various gram-positive coryneform bacteria. J Bacteriol 172, 1663-1666.

Schwarzer, A. \& Pühler, A. (1991). Manipulation of Corynebäcterium glutamicum by gene disruption and replacement. Bio/Technology $\mathbf{9}$, 84-87.

Segel, I. H. (1975). Enzyme Kinetics. New York: Wiley Interscience. Simon, R., Priefer, U. \& Pühler, A. (1983). A broad host range mobilization system for in vivo genetic engineering: transposon mutagenesis in gram negative bacteria. Bio/Technology 1, 784-791.

Thomas, G. H., Connerton, I. F. \& Fincham, J. R. S. (1988). Molecular cloning, identification and transcriptional analysis of genes involved in acetate utilization in Neurospora crassa. Mol Microbiol 2, 599-606.

Tinoco, I., Borer, P. N., Dengler, B., Levine, M. D., Uhlenbeck, O. C., Crothers, D. M. \& Gralla, J. (1973). Improved estimation of secondary structure in ribonucleic acid. Nature New Biol 246, 40-41.

Vanderwinkel, E. \& De Vlieghere, M. (1968). Physiologie et genetique de l'isocitritase et des malate synthases chez Escherichia coli. Eur J Biochem 5, 81-90.

Vieira, J. \& Messing, J. (1982). The pUC plasmids, an M13mp7derived system for insertion mutagenesis and sequencing with synthetic universal primers. Gene 19, 259-268.

Wiegand, G. \& Remington, S. J. (1986). Citrate synthesis : structure, control, and mechanism. Annu Rev Biophys Biophys Chem 15, 97-117.

Wilson, R. B. \& Maloy, S. R. (1987). Isolation and characterization of Salmonella typhimurium glyoxylate shunt mutants. J Bacteriol 169, 3029-3034.

Received 13 May 1994; accepted 24 June 1994. 